\title{
Función de apantallamiento de interferencia electromagnética de pastas de cemento con materiales carbonosos y cenizas volantes procesadas
}

\author{
Electromagnetic interference shielding with Portland cement paste \\ containing carbon materials and processed fly ash
}

\author{
E. Zornoza $(*)$, G. Catalá(*), F. Jiménez ${ }^{(* *)}$, L. G ${ }^{a}$ Andión ${ }^{(*)}, \underline{\text { P. Garcés }}^{(*)}$
}

Recepción/Received: 26-II-09

Aceptación/Accepted: 21-IV-09

Publicado online/Online publishing: 17-XII-10

\section{RESUMEN}

En el presente trabajo se investiga la influencia de la adición de diferentes tipos de materiales carbonosos (polvo de grafito y 3 tipos de fibra de carbono), de una ceniza volante con diferentes contenidos de fase magnética $\left(5,6 \%, 15,9 \%\right.$ y $24,3 \%$ de $\left.\mathrm{Fe}_{2} \mathrm{O}_{3}\right)$ y de una mezcla de ambos, sobre la capacidad de apantallar interferencias electromagnéticas de pastas de cemento Pórtland. Entre los parámetros estudiados se encuentra: el tipo de material carbonoso, la relación de aspecto del material carbonoso, el espesor del material compuesto, la frecuencia de la radiación electromagnética incidente y el porcentaje de fracción magnética en la ceniza volante. Los resultados obtenidos indican que entre los materiales carbonosos estudiados son las fibras de carbono basadas en poliacrilonitrilo con una mayor relación de aspecto las que dan mejores resultados de apantallamiento. Al aumentar el espesor del material compuesto o la frecuencia de radiación también aumenta la eficacia del apantallamiento. En lo que respecta a la ceniza volante, el incremento de la fracción magnética de la ceniza incrementa el nivel de apantallamiento. No obstante, los resultados más eficaces se obtienen por la adición conjunta de fibras de carbono y ceniza volante debido a un efecto sinérgico.

Palabras clave: Apantallamiento EMI, pasta de cemento, ceniza volante procesada, fibra de carbono, polvo de grafito.

\section{ABSTRACT}

The study described in this article explored the effect of adding different types of carbon materials (graphite powder and three types of carbon fibre), fly ash (with $5.6 \%, 15.9 \%$ and $24.3 \% \mathrm{Fe}_{2} \mathrm{O}_{3}$ ), and a mix of both on electromagnetic interference (EMI) shielding in Portland cement pastes. The parameters studied included the type and aspect ratio of the carbonic material, composite material thickness, the frequency of the incident electromagnetic radiation and the percentage of the magnetic fraction in the fly ash. The findings showed that the polyacrylonitrile-based carbon fibres, which had the highest aspect ratio, provided more effective shielding than any of the other carbon materials studied. Shielding was more effective in thicker specimens and at higher radiation frequencies. Raising the magnetic fraction of the fly ash, in turn, also enhanced paste shielding performance. Finally, adding both carbon fibre and fly ash to the paste resulted in the most effective EMI shielding as a result of the synergies generated.

Keywords: EMI shielding, cement paste, processed fly ash, carbon fibre, graphite powder.

\footnotetext{
(*) Universidad de Alicante (España).

(**) Universidad Politécnica de Madrid (España).
} 


\section{INTRODUCCIÓN}

Los materiales cementantes tienen una gran importancia en el campo de la ingeniería estructural debido a sus propiedades mecánicas, buena durabilidad y bajo coste. Sin embargo, durante los últimos años, se está haciendo un esfuerzo para aumentar la funcionalidad de este material estructural y obtener un mayor rendimiento del mismo (1). Esta investigación se ha enfocado en la mejora del apantallamiento de interferencia electromagnética (EMI) ofrecida por los materiales cementantes. Esta aplicación está aumentando en interés en la sociedad actual debido al creciente uso de dispositivos electrónicos que se ven afectados por las radiaciones ambientales, especialmente por la radiación de radiofrecuencias. Durante los últimos años, el uso de tecnologías inalámbricas ha aumentado significativamente, siendo necesario proteger de este tipo de radiaciones algunos edificios, instalaciones o habitaciones, por ejemplo, en hospitales, edificios militares o gubernamentales, estaciones eléctricas o instalaciones estratégicas (2-4).

Las matrices cementantes no son eléctricamente conductoras, sino que se comportan como materiales dieléctricos. Por esta razón, es necesario introducir adiciones eléctricamente conductoras o ciertas cantidades de dipolos eléctricos o magnéticos para obtener un buen apantallamiento EMI (2). En esta investigación, se ha incorporado fibras de carbono (FC) y la fracción magnética de ceniza volante procesada (MFA) en pastas de cemento. Las fibras de carbono son eléctricamente conductoras y la ceniza volante magnética ofrece una alta concentración de $\mathrm{Fe}_{2} \mathrm{O}_{3}$, el cual es un dipolo magnético, por lo que se espera que ambos materiales mejoren la capacidad de apantallamiento EMI de los materiales que únicamente llevan cemento. La ceniza volante común, contiene una mayor concentración de $\mathrm{Fe}_{2} \mathrm{O}_{3}$ que el cemento Portland (5-8), por lo que ofrece cierto incremento en el nivel de apantallamiento cuando se usa en combinación con el cemento Portland (9). En este trabajo se ha usado la fracción magnética de la ceniza volante, las cual ofrece una muy alta concentración de $\mathrm{Fe}_{2} \mathrm{O}_{3}(10)$.

Con objeto de obtener un buen apantallamiento EMI en habitaciones, es más práctico usar una matriz cementicia que una matriz polimérica debido al menor coste del cemento en comparación con los polímeros y la menor eficiencia de apantallamiento que muestran los polímeros, ya que estos materiales son menos conductores (11).

En los últimos años, se ha investigado el comportamiento de apantallamiento EMI de distintos tipos de adiciones en composites de matriz cementicia (1-4, 9, 11-28). Estas investigaciones se centraron principalmente en adiciones metálicas como el níquel, el acero y el cobre. En términos generales, los metales muestran un buen

\section{INTRODUCTION}

Cementitious materials are of key importance in structural engineering because of their mechanical strength, durability and low cost. In recent years, however, efforts have been made to draw further benefits from this material by broadening its functionality (1). The present research focused on improving the electromagnetic interference (EMI) shielding afforded by cementitious materials. Interest in this property is growing in today's society due to the widespread use of electronic devices that are impacted by environmental radiation, particularly radio frequency radiation. The mushrooming of wireless technologies in the last few years has created a need to provide radiation protection in sensitive areas such as hospitals, military or governmental buildings, electric power plants or strategic facilities (2-4).

Cementitious materials do not conduct electricity, but rather behave as dielectric materials. To serve as an EMI shield, then, they must be additioned with electrically conductive products or certain amounts of electric or magnetic dipoles (2). In this study, two materials expected to improve EMI shielding capacity were added to cement pastes: carbon fibres (CF), which are electrical conductors, and the magnetic fraction of processed fly ash (MFA), which has a high concentration of the magnetic dipole $\mathrm{Fe}_{2} \mathrm{O}_{3}$. Common fly ash has a higher $\mathrm{Fe}_{2} \mathrm{O}_{3}$ content than Portland cement (5-8) and hence increases its shielding power moderately when added to the cement matrix (9). This study explored the effect of its magnetic fraction, which has a very high $\mathrm{Fe}_{2} \mathrm{O}_{3}$ content (10).

To effectively shield indoor areas from EMI, cementitious matrices are more practical than polymer matrices due to the lower cost of cement and the lower shielding efficiency of polymers, which are less electrically conducive (11).

EMI shielding behaviour has been studied in recent years for different types of composite additions included in the cementitious matrix (1-4, 9, 11-28). These studies have focused primarily on metallic additions such as nickel, steel and copper. As a rule, while metals constitute good EMI shields due to their effectiveness in reflecting 
apantallamiento EMI debido a la elevada reflexión a las radiaciones que ofrecen, aunque las dimensiones de los materiales adicionados es un parámetro tan importante como el propio material. Este hecho surge del llamado "efecto piel" $(2,18)$ el cual hace referencia a que la reflexión de las radiaciones se produce en la superficie del material reflectante, haciendo que la radiación sólo penetre unas pocas micras (dependiendo del propio material) en la superficie del material considerado. El mecanismo de apantallamiento por reflexión es normalmente más importante en la capacidad de apantallamiento EMI, por lo que es recomendable usar estos materiales conformados de forma que tenga un pequeño tamaño y una elevada relación de aspecto, es decir, en forma de fibras, nanofibras o nanopartículas, ya que éstos ofrecen una gran relación superficie/volumen y dotan al material de una entramado eléctrico más desarrollado.

Usando una combinación de materiales carbonosos, ceniza volante y cemento se puede mejorar la funcionalidad del hormigón, cuya principal función es puramente estructural, hacia un material multifuncional que mantenga su buen comportamiento mecánico y que además ofrezca propiedades de apantallamiento EMI. El objetivo de esta investigación ha sido establecer el nivel de apantallamiento EMI de pastas de cemento con adición de diferentes materiales carbonosos (polvo de grafito, fibras de carbono largas y fibras de carbono cortas) y distintas fracciones de ceniza volante (sin procesar, fracción magnética y fracción no magnética).

\section{EXPERIMENTAL}

Se han fabricado probetas de pasta de cemento cilíndricas de $12 \mathrm{~cm}$ de diámetro y 4 o $10 \mathrm{~cm}$ de espesor (Figura 1). Se ha usado cemento Portland tipo CEM I 52,5 R para la preparación de las pastas. La composición química del cemento se muestra en la Tabla 1 . Todas las mezclas se radiation, the dimensions of the additions are as important for these intents and purposes as the nature of the material because of the so-called "skin effect" (2, 18). This term refers to the fact that radiation is reflected at the surface of reflective materials and therefore penetrates only a few microns (depending on the material in question) below. Since reflection shielding is normally the primary mechanism in EMI shielding capacity, the highest performers are small particles with a high aspect ratio, i.e., fibres, nanofibres or nanoparticles, which have a large surface/volume ratio and form a denser electrical lattice.

A combination of carbon materials, fly ash and cement can convert concrete from a purely structural to a multipurpose material that maintains high mechanical strength while affording EMI shielding. The present study aimed to establish the effectiveness of EMI shielding in cement pastes containing carbon materials (graphite powder, long and short carbon fibre) and different fractions of fly ash (raw, magnetic and nonmagnetic).

\section{EXPERIMENTAL}

Cylindrical cement paste specimens measuring $12 \mathrm{~cm}$ in diameter and 4 or $10 \mathrm{~cm}$ thick (high) were prepared (Figure 1). CEM I 52.5 R Portland cement was used throughout. The chemical composition of the cement is given in Table 1. All the mixes were prepared with a

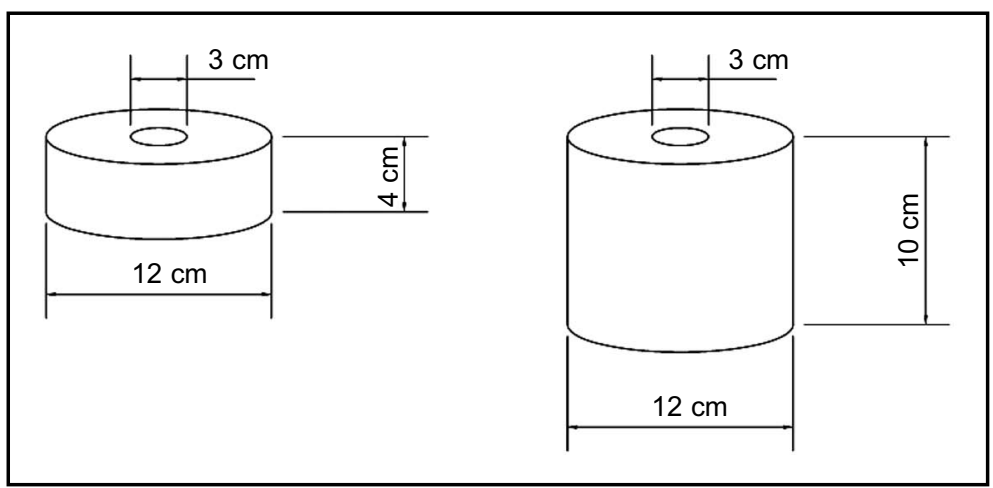

Figura 1. Esquema de las probetas de pasta de cemento preparadas para los ensayos de apantallamiento EMI.

Figure 1. Sketch of cement paste specimens prepared for EMI shielding test. 
Tabla 1 / Table 1

Composición química porcentual del cemento Portland.

Chemical composition (per cent) of the Portland cement used.

\begin{tabular}{|c|c|c|c|c|c|c|c|c|c|}
\hline $\mathrm{SiO}_{2}$ & $\mathrm{Al}_{2} \mathrm{O}_{3}$ & $\mathrm{Fe}_{2} \mathrm{O}_{3}$ & $\mathrm{CaO}$ & $\mathrm{MgO}$ & $\mathbf{S O}_{3}$ & $\mathrm{~K}_{2} \mathrm{O}$ & $\mathrm{Cl}^{-}$ & $\begin{array}{c}\mathrm{R}^{*} \\
\mathbf{I R}^{*}\end{array}$ & $\begin{array}{c}\mathrm{PF}^{*} \\
\text { LOI }^{*}\end{array}$ \\
\hline 19.2 & 4.9 & 2.7 & 61.8 & 2.6 & 6.3 & 0.93 & 0.02 & 3.2 & 0.95 \\
\hline
\end{tabular}

*RI: residuo insoluble; PF: pérdida al fuego. / *IR: insoluble residue; LOI: loss on ignition.

han preparado con una relación agua/material cementante $(\mathrm{a} / \mathrm{mc})$ igual a 0,35 . Se han usado tres tipos de fibras de carbono: Donacarbo de $3 \mathrm{~mm}$ de longitud y $15 \mu \mathrm{m}$ de diámetro (DON3), Sigrafil de $3 \mathrm{~mm}$ de longitud (SIG3) y Sigrafil de $6 \mathrm{~mm}$ de longitud (SIG6), ambas con $7 \mu \mathrm{m}$ de diámetro. Esto ha dado como resultado el poder utilizar fibras de carbono con tres relaciones de aspecto distintas: 200 para la Donacarbo de 3 mm, 428 para la Sigrafil de 3 $\mathrm{mm}$ y 857 para la Sigrafil de $6 \mathrm{~mm}$. La fibra de carbono Sigrafil es un material carbonoso basado en poliacrilonitrilo (PAN), mientras que la fibra Donacarbo es un material más económico basado en brea de petróleo. También se ha usado como adición carbonosa polvo de grafito (GP) cuyo diámetro es de $75 \mu \mathrm{m}$ suministrado por Superior Graphite, S.L. La relación de aspecto del polvo de grafito se puede asumir que es aproximadamente igual a 1, ya que está compuesto de partículas redondeadas. Se ha usado ceniza volante de la central eléctrica de Teruel como sustitución parcial de cemento. Esta ceniza volante presenta un diámetro de partícula comprendido entre 3 y $300 \mu \mathrm{m}$. Esta puzolana se ha utilizado diferenciando distintas fracciones de la misma según sus propiedades magnéticas. Por un lado se han fabricado pastas en las que se incluía la ceniza volante sin tratar (FA0). Por otra parte también se aplicó un tratamiento de separación magnético para obtener dos fracciones distintas: una de ellas presentaba comportamiento magnético (ceniza volante magnética, MFA), y la otra no interactuaba con el campo magnético (ceniza volante no magnética, NMFA). La composición química de cada una de las fracciones se presenta en la Tabla 2. Finalmente, se utilizó metilcelulosa en una proporción del $0,4 \%$ en peso en aquellas mezclas que incorporaban fibras de carbono para mejorar la dispersión de las fibras en la matriz durante el proceso de amasado. La Tabla 3 resumen las dosificaciones de las probetas elaboradas en este trabajo. water/cementitious material $(w / \mathrm{cm})$ ratio of 0.35 . Three types of carbon fibres were used: Donacarbo DON3 (3mm long, $15 \mu$ m diameter), Sigrafil SIG3 (3- $\mathrm{mm}$ long, 7 $\mu \mathrm{m}$ in diameter) and SIG6 (6- $\mathrm{mm}$ long, $7 \mu \mathrm{m}$ in diameter). These fibres had different aspect ratios: 200 for 3-mm Donacarbo, 428 for 3-mm Sigrafil and 857 for 6-mm Sigrafil. Sigrafil carbon fibre is a polyacrylonitrile (PAN)-based carbonic material, whereas Donacarbo is a less expensive, petroleum tar-based material. Graphite powder (GP) with round particles (and hence with an aspect ratio of approximately 1) $75 \mu \mathrm{m}$ in diameter, supplied by Superior Graphite S.L., was also used as a carbonic addition. Fly ash from the Teruel electric power plant whose particles ranged in diameter from 3 to 300 $\mu \mathrm{m}$ was used as a partial replacement for cement. Three variations of this pozzolan were defined in terms of their magnetic properties. Some of the pastes were prepared with raw or untreated fly ash (FAO). In others, the ash was first separated magnetically into two fractions: one exhibiting magnetic behaviour (magnetic fly ash, MFA) while the other unable to interact with magnetic fields (non-magnetic fly ash, NMFA). The chemical compositions of the fractions are given in Table 2. Finally, $0.4 \%$ (wt) methyl cellulose was added to the mixes containing carbon fibres to enhance fibre dispersion in the matrix during mixing. Table 3 summarizes the dosages used to prepare the specimens made for this study.

Tabla 2 / Table 2

Composición química porcentual de las distintas fracciones de ceniza volante empleadas [19]. Chemical composition (per cent) of the fly ash fractions used [19].

\begin{tabular}{|c|c|c|c|c|c|c|}
\hline Ceniza volante / Fly Ash & $\mathbf{S i O}_{\mathbf{2}}$ & $\mathbf{F e}_{2} \mathbf{O}_{\mathbf{3}}$ & $\mathbf{A l}_{2} \mathbf{O}_{\mathbf{3}}$ & $\mathbf{C a O}$ & $\mathbf{M g O}$ & $\begin{array}{c}\mathbf{P F}^{*} \\
\text { LO/ }^{*}\end{array}$ \\
\hline $\mathrm{T} 0 / \mathrm{T} 60$ & 41.40 & 15.95 & 26.22 & 6.10 & 1.11 & 2.20 \\
\hline $\mathrm{TM}$ & 28.7 & 24.3 & 34.4 & 7.4 & 1.5 & 0.5 \\
\hline $\mathrm{TNM}$ & 42.5 & 5.6 & 31.4 & 11.7 & 2.0 & 1.8 \\
\hline
\end{tabular}

*PF: Pérdida al fuego. / *LOI: loss on ignition. 
Tabla 3 / Table 3

Dosificaciones de las probetas ensayadas. Porcentaje de adición de los materiales carbonosos y porcentaje de sustitución de la ceniza volante, respecto masa de cemento.

Specimen dosage. Percentage (by cement mass) of carbonic material additions and fly ash replacement rate.

\begin{tabular}{|c|c|c|c|c|c|c|c|}
\hline $\begin{array}{c}\text { Probeta I } \\
\text { Specimen }\end{array}$ & FA0 & MFA & NMFA & DON3 & SIG3 & SIG6 & GP \\
\hline Control & - & - & - & - & - & - & - \\
\hline FA0 & 30 & - & - & - & - & - & - \\
\hline MFA & - & 30 & - & - & - & - & - \\
\hline NMFA & - & - & 30 & - & - & - & - \\
\hline DON3 & - & - & - & 0.5 & - & - & - \\
\hline SIG3 & - & - & - & - & 0.5 & - & - \\
\hline SIG6 & - & - & - & - & - & 0.5 & - \\
\hline GP & - & - & - & - & - & - & 0.5 \\
\hline FA0-SIG3 & 30 & - & - & - & 0.5 & - & - \\
\hline FA0-SIG6 & 30 & - & - & - & - & 0.5 & - \\
\hline FA0-GP & 30 & - & - & - & - & - & 0.5 \\
\hline MFA-SIG6 & - & 30 & - & - & - & 0.5 & - \\
\hline NMFA-SIG6 & - & - & 30 & - & - & 0.5 & - \\
\hline
\end{tabular}

Las probetas se fabricaron en moldes de cobre, los cuales se anclaban posteriormente a la célula de medida de apantallamiento EMI para medir el rendimiento de cada una de las pastas elaboradas (Figura 2). Las probetas se curaron durante 28 días en una cámara húmeda con un $100 \%$ de humedad relativa y una temperatura de $20^{\circ} \mathrm{C}$. Posteriormente se practicaba el ensayo de apantallamiento a cada una de las pastas. El parámetro de apantallamiento EMI se midió mediante un analizador de redes Agilent, modelo E506x, cuya impedancia nominal es de $50 \mathrm{ohm}$. Las probetas se midieron en el intervalo de frecuencias comprendidas entre $300 \mathrm{MHz}$ y $3 \mathrm{GHz}$. El comportamiento de apantallamiento EMI se evaluó a través del parámetro de apantallamiento $(S)$ y este resultado se corresponde con la media de los valores obtenidos en los sentidos de incidencia de la radiación sobre la probeta. El apantallamiento EMI (S) se calculó mediante la Ecuación 1 (20), donde $\mathrm{I}_{\mathrm{e}}$ es la intensidad de la radiación
The specimens were cast and subsequently cured in copper moulds for 28 days in a humidity chamber at $100 \%$ relative humidity and $20{ }^{\circ} \mathrm{C}$. Thereafter, the moulded specimens were anchored to an EMI measurement cell and tested to determine paste shielding performance (Figure 2). The test apparatus was an Agilent E506x network analyzer with a nameplate impedance of 50 ohms that measured specimen radiation over a frequency range of $300 \mathrm{MHz}$ to $3 \mathrm{GHz}$. The EMI shielding performance $(S)$ values shown are the mean of the measurements obtained in the direction of the incident radiation. EMI shielding $(S)$ was calculated from Equation $1(20)$, where $I_{e}$ is the intensity of the radiation emitted and $I_{r}$ is the intensity of the radiation received by the network analyzer. Further to the set-up diagram in Figure 2, which had been used in prior studies (17, 23), radiation was emitted by one of the network analyzer ports onto the specimen surface (where a certain portion

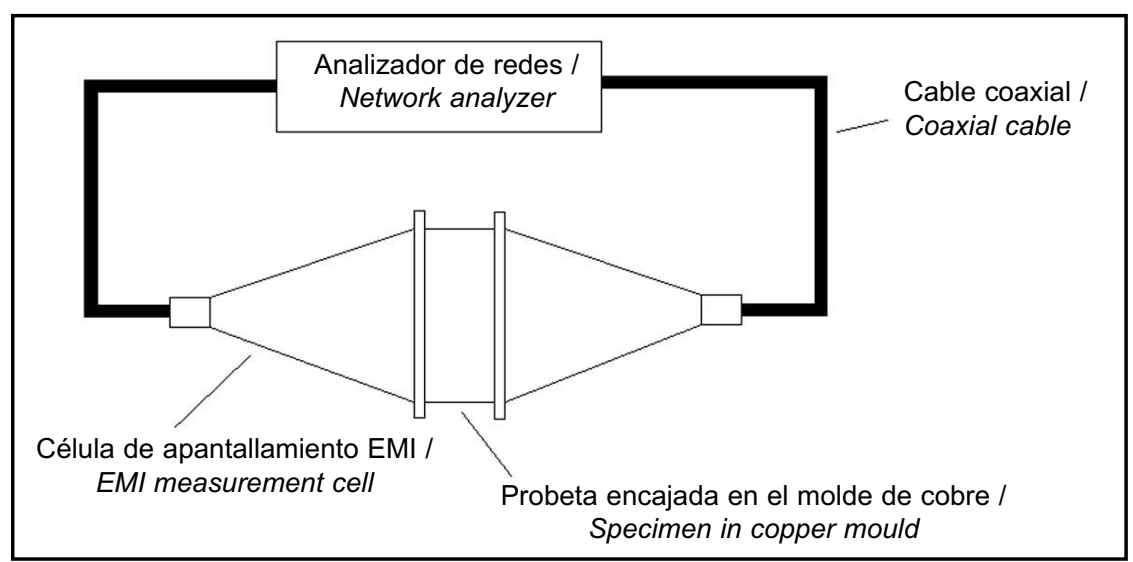

Figura 2. Esquema de la célula de medida de apantallamiento EMI. Figure 2. Sketch of EMI measurement cell. 
emitida e $\mathrm{I}_{\mathrm{r}}$ es la intensidad de la radiación recibida por el analizador de redes. Según el montaje que se detalla en la Figura 2, el cual se ha empleado en otros estudios $(17,23)$, la radiación se emite por uno de los puertos del analizador de redes, alcanza la superficie de la probeta (donde cierta cantidad de intensidad se pierde por reflexión), atraviesa la probeta (donde otra fracción de intensidad se pierde por absorción) y finalmente, la radiación se recibe en el otro puerto del analizador de redes. of the intensity was lost due to reflection), crossed through the specimen (where another fraction was lost due to absorption) and ultimately received at the other network analyzer port.

\section{RESULTADOS Y DISCUSIÓN}

La Figura 3 presenta el nivel de apantallamiento EMI a $1,0 \mathrm{GHz}$ para distintas pastas de cemento con espesor de $4 \mathrm{~cm}$, que contienen distintos tipos de material carbonoso. Se puede observar que hay diferencias muy significativas en el comportamiento de apantallamiento dependiendo del tipo de material carbonoso considerado. Las pastas con GP casi no modifican la eficiencia de apantallamiento ya que su valor de apantallamiento es aproximadamente el mismo mostrado por la pasta Control. No obstante, cuando el material carbonoso es una fibra, hay un importante aumento de la capacidad de apantallamiento del material. Además, se puede apreciar que existe una clara dependencia del valor de apantallamiento según se modifica la relación de aspecto. La Figura 4 muestra esta dependencia, así como el ajuste de los datos a una ecuación lineal empírica [2], donde $I / d$ es la relación de aspecto (longitud/diámetro) del material carbonoso. Por tanto, se puede afirmar que la relación de aspecto de la adición es un parámetro crítico

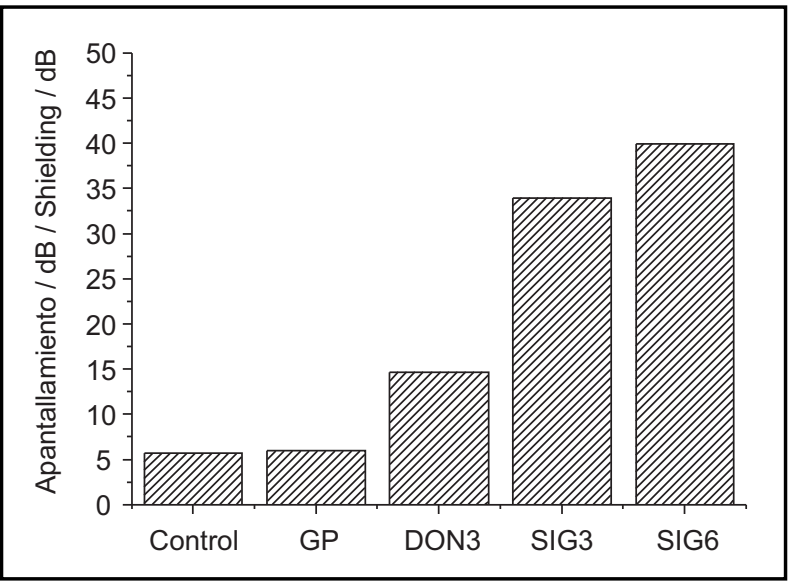

Figura 3. Apantallamiento de radiación de las pastas de cemento con varios tipos de materiales carbonosos a 1,0 GHz. El espesor de las probetas es de $4 \mathrm{~cm}$.

Figure 3. EMI shielding at $1.0 \mathrm{GHz}$ in $4-\mathrm{cm}$ cement paste specimens containing carbonic materials.

\section{RESULTS AND DISCUSSION}

Figure 3 shows the 1.0-GHz EMI shielding effectiveness for the 4-cm thick cement paste specimens containing different types of carbonic material. Very significant differences were observed depending on the carbonic material used. GP pastes barely affected shielding efficiency, exhibiting approximately the same shielding values as the control paste. When the carbonic material used was fibrous, however, shielding capacity was considerably higher than in the control. Moreover, as shown in Figure 4, shielding values were found to be heavily dependent on aspect ratio. The figure also shows the data fit to an empirical linear equation [2], where $1 / d$ is the aspect ratio (length/diameter) of the carbonic material. The aspect ratio of the addition may therefore be regarded to be a critical parameter in improving the shielding performance of the composite material. Moreover, where higher performance is pursued, raising the aspect ratio may be more cost-effective than increasing the amount of carbonic material, for these

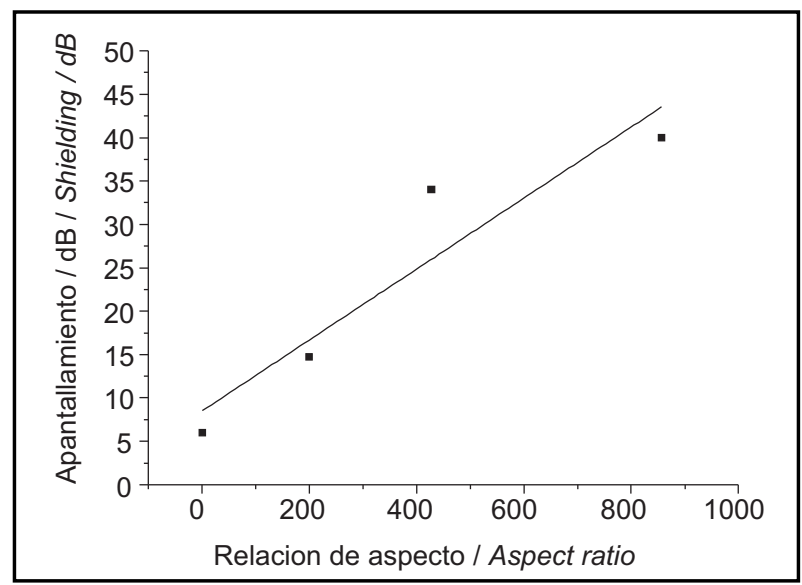

Figura 4. Relación entre el apantallamiento EMI a $1.0 \mathrm{GHz}$ y la relación de aspecto del material carbonoso usado como adición en probetas con $4 \mathrm{~cm}$ de espesor.

Figure 4. EMI shielding at $1.0 \mathrm{GHz}$ versus aspect ratio of carbonic material additioned to 4-cm specimens. 
a la hora de mejorar el comportamiento de apantallamiento del material compuesto, y que en términos de coste puede resultar más interesante aumentar la relación de aspecto que aumentar la cantidad de material carbonoso para obtener un mejor rendimiento del material compuesto ya que estas adiciones son la parte que más encarece el producto final. additions are the component with the greatest impact on the cost of the end product. donde $S$ es el apantallamiento, I es la longitud de la fibra empleada y $d$ es el diámetro de dicha fibra.

En la Figura 5 se representan los valores de apantallamiento EMI de las probetas de pasta de cemento de $4 \mathrm{~cm}$ espesor que contienen SIG6 para diferentes frecuencias. Tal y como se esperaba, la eficiencia de apantallamiento de las probetas es mayor cuando la frecuencia de la radiación aumenta, puesto que la reflexión aumenta según aumenta la frecuencia y éste es el mecanismo principal de apantallamiento (18). Esto es una tendencia general observada en la mayor parte de los materiales (2). Al aumentar la frecuencia, el campo electromagnético se refleja en la superficie en un alto porcentaje y en el interior se atenúa rápidamente, por lo que se dice que sólo penetra unas pocas micras, o incluso menos, en un material conductor. Se define la "profundidad de piel o penetración" $(2,18)$ como la distancia a la que la amplitud de la onda incidente disminuye en un factor de $e$, es decir, la profundidad que debe penetrar la onda dentro del material para que su amplitud sea $1 /$ e veces su valor inicial. La intensidad del campo eléctrico disminuye exponencialmente dentro de un material conductor. Por otra parte, la profundidad de piel disminuye cuando aumenta la frecuencia, como se muestra en la Ecuación [3]: where $S$ is shielding, I is the length of the fibre and $d$ its diameter.

Figure 5 diagrams the EMI shielding values for the 4-cm SIG6-containing cement paste specimens by frequency. As expected, shielding efficiency in the specimens was greater at higher radiation frequencies, for reflection, the mechanism that primarily governs shielding, rises with frequency (18). This pattern is observed in most materials (2). At higher frequencies, a higher percentage of the electromagnetic field is reflected off the surface and is quickly attenuated in the interior. As a result, the radiation only penetrates a few microns, or even less, into a conductor. The "skin or penetration depth" $(2,18)$ is defined to be the distance at which the amplitude of the incident wave declines by a factor of e, i.e., the depth that the wave must penetrate into the material for its amplitude to drop to 1/e times the initial value. The intensity of an electric field declines exponentially inside a conductor. Furthermore, skin depth declines with rising frequency, as shown in Equation [3]:

$$
\delta=\frac{1}{\sqrt{\pi \cdot f \cdot \mu \cdot \sigma}}
$$

donde $\delta$ es la profundidad de piel $(\mathrm{m}), f$ es la frecuencia de la radiación $(\mathrm{Hz}), \mu$ es la permeabilidad magnética del conductor $(\mathrm{H} / \mathrm{m})$ y $\sigma$ es la conductividad eléctrica del material $\left(\Omega^{-1} \mathrm{~m}^{-1}\right)$. Una menor profundidad de piel se traduce en una mejor respuesta del material, es decir, en una mayor capacidad de apantallamiento.

En la Figura 6 se puede apreciar la influencia del espesor de la probeta en el nivel de apantallamiento de la radiación electromagnética de $0,5 \mathrm{GHz}$. En dicha gráfica de nuevo se confirma que la fibra de carbono con mayor relación de aspecto ofrece los mejores valores de apantallamiento. Además, como era de esperar, un aumento del espesor de la probeta produce un aumento considerable del apantallamiento, ya que, por ejemplo, en el where $\delta$ is the skin depth $(m), f$ the radiation frequency $(\mathrm{Hz}), \mu$ the magnetic permeability of the conductor $(\mathrm{H} / \mathrm{m})$ and $\sigma$ the electrical conductivity of the material $\left(\Omega^{1} m^{-1}\right)$. The smaller the skin depth, the better the response, i.e., the greater the shielding capacity.

Figure 6 shows the effect of specimen thickness (height) on $0.5-\mathrm{GHz}$ electromagnetic radiation shielding. The graph confirms that the carbon fibre with the highest aspect ratio provided the highest shielding values. Moreover, as expected, greater specimen thicknesses led to substantial rises in shielding efficiency. For SIG6, for instance, the 4-cm specimen shielding value was $27.0 \mathrm{~dB}$ or $95.3 \%$ of the intensity of the incident radiation, while 


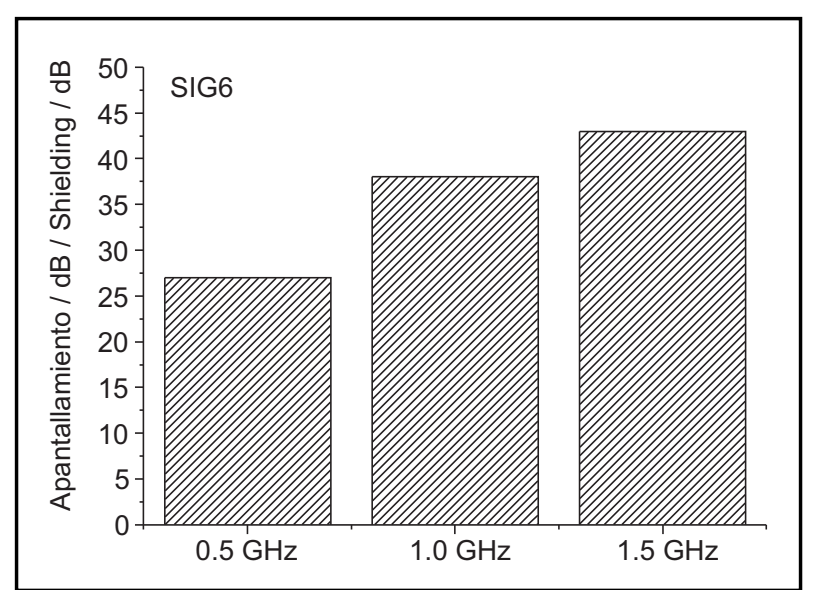

Figura 5. Apantallamiento EMI a distintas frecuencias para probetas con SIG6 y $4 \mathrm{~cm}$ de espesor.

Figure 5. EMI shielding in 4-cm paste specimens containing SIG6, by frequency.

caso de la probeta con SIG6 y $4 \mathrm{~cm}$, el apantallamiento es de $27,0 \mathrm{~dB}$, lo que significa que se apantalla el $95,53 \%$ de la intensidad de radiación incidente; por su parte, para la misma probeta pero con espesor de $10 \mathrm{~cm}$ el apantallamiento es de $44,5 \mathrm{~dB}$, lo que implica el apantallamiento del $99,40 \%$ de la intensidad de radiación incidente. Dado que las pérdidas por reflexión tienen que ser iguales en la de $4 \mathrm{~cm}$ y en la de $10 \mathrm{~cm}$, la diferencia entre ellas se debe a la atenuación de la señal al atravesar el material, por tanto con este tipo de gráficas se puede visualizar si el apantallamiento principal es por reflexión o por atenuación. Observando los valores obtenidos en la Figura 6 se aprecia que la fibra DON3 produce una absorción muy baja, mientras que en la fibra de carbono SIG3 y SIG6 consigue mejorar de forma importante el apantallamiento de la radiación a través del mecanismo de absorción, a la vez que la reflexión es también mayor que en el caso de la fibra DON3.

La Figura 7 muestra los resultados de apantallamiento de radiación electromagnética ofrecidos por las probetas de $4 \mathrm{~cm}$ de espesor y con las distintas fracciones de ceniza volante ensayadas en este trabajo. Se puede apreciar nuevamente que al aumentar la frecuencia de la radiación incidente, el nivel de apantallamiento aumenta en todos los casos. Por otra parte, con respecto a la respuesta de cada una de las fracciones de ceniza volante se observa lo siguiente: la ceniza volante original (FAO) mejora ligeramente la capacidad de apantallamiento de la probeta respecto a la pasta control en todos los casos; las probetas que incorporan ceniza volante no magnética (NMFA) ofrecen un comportamiento ligeramente peor que el mostrado por la pasta Control; finalmente, la sustitución de cemento por ceniza volante magnética (MFA) mejora claramente los niveles de apantallamiento con respecto a los obtenidos

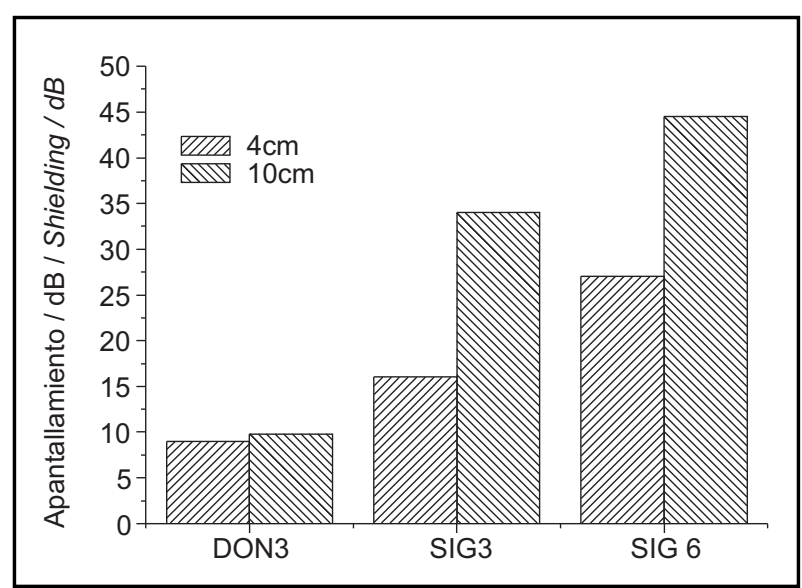

Figura 6. Apantallamiento EMI a $0,5 \mathrm{GHz}$ de probetas de pasta de cemento con distintas fibras de carbono y espesores de 4 y $10 \mathrm{~cm}$.

Figure 6. EMI shielding on $0.5 \mathrm{GHz}$ in 4 - and $10-\mathrm{cm}$ cement paste specimens, by type of carbon fibre.

the value for the $10 \mathrm{~cm}$ specimen was $44.5 \mathrm{~dB}$ or $99.40 \%$ of the radiation intensity. Given that reflection loss must be the same in the 4- and 10-cm specimens, the difference between the two was due to signal attenuation as it crossed the material. Consequently, this type of graph shows whether shielding is primarily due to reflection or attenuation. Pursuant to the values given in Figure 6, DON3 fibre exhibited very low absorption, while the SIG3 and SIG6 carbon fibres improved absorption-mediated radiation shielding substantially and their reflection values were also higher than for the DON3 fibre.

Figure 7 shows the electromagnetic radiation shielding values found for the 4-cm specimens containing the three fly ash fractions tested in this study. Here also, shielding effectiveness grew with rising incident radiation frequency. At the same time, the original fly ash (FAO) exhibited slightly more effective shielding capacity than the control paste in all cases, while the specimens containing non-magnetic fly ash (NMFA) performed slightly worse than the control paste. Lastly, replacing cement with magnetic fly ash (MFA) led to clearly greater shielding effectiveness than recorded for the control pastes. The three fractions of fly ash differed primarily in their iron oxide (specifically, magnetite) content. As magnetic dipoles, these compounds moderately enhanced specimen shielding capacity. Since the original fly ash (FAO) had a higher proportion of iron oxides than Portland cement, shielding was slightly more effective in 
con las pastas Control que solamente incorporan cemento Portland. La principal diferencia que aportan cada una de las fracciones de la ceniza volante es el contenido en óxidos de hierro (magnetita, concretamente), los cuales, como dipolos magnéticos que son, aportan cierta capacidad de apantallamiento a las probetas. Por una parte, la ceniza volante original (FA0) contiene una mayor proporción de estos compuestos que el cemento Portland por lo que su influencia es aumentar ligeramente el nivel de apantallamiento con respecto al cemento Portland. Por otro lado, la fracción no magnética (NMFA) se encuentra empobrecida con respecto al contenido magnetita ya que para obtener dicha fracción, se extraen las partículas de alto contenido en magnetita mediante el tratamiento magnético, de ahí que su efecto sea diluir la concentración de este mineral del cemento Portland cuando se sustituye parte de éste por la ceniza volante no magnética (NMFA), mostrando efectivamente, un descenso ligero de los valores de apantallamiento. Finalmente, la fracción magnética (MFA) se encuentra enriquecida en magnetita, por lo que el material cementante resultante de su combinación con el cemento Portland contiene una mayor concentración de dipolos magnéticos que el cemento Porltand original, por lo que el nivel de apantallamiento mostrado por la pasta con MFA es claramente mejor que la pasta Control.

Pese a que no se obtiene mejoras en el apantallamiento de la magnitud que puedan producir otros materiales como el acero o las fibras de carbono, una de las razones por las cuales puede ser interesante el uso de ceniza volante es su precio (mucho más bajo que el acero o las fibras de carbono) y su fácil dispersión en la matriz de cemento.

La Figura 8 muestra los niveles de apantallamiento obtenidos con distintos materiales carbonosos con una

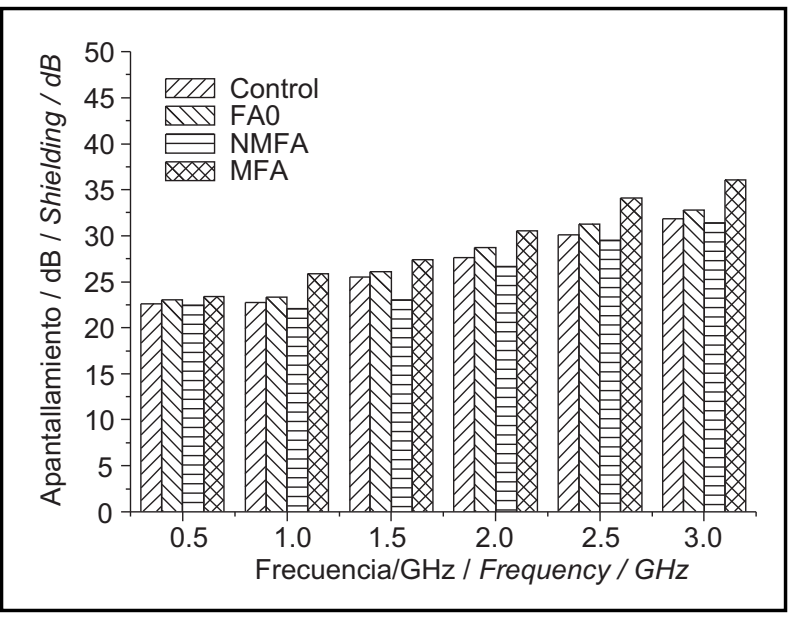

Figura 7. Apantallamiento EMI de probetas de pasta de cemento con distintas fracciones de ceniza volante a distintas frecuencias. Espesor de las probetas: $4 \mathrm{~cm}$.

Figure 7. EMI shielding in 4-cm cement paste specimens containing different fractions of fly ash, by frequency. these than in the control specimens. The non-magnetic fraction, (NMFA) in turn, had a very low magnetite content, for it was obtained by magnetically extracting the particles with a high iron content. Consequently, the effect of adding it to the Portland cement was to dilute the concentration of this mineral in the blend and with it the shielding values. Finally, when the magnetite-rich magnetic fraction (MFA) was added to the original Portland cement, it raised the concentration of magnetic dipoles. The result was clearly more efficient shielding than in the control paste.

Although fly ash improved shielding less substantially than other materials such as steel or carbon fibres, it may prove to be a useful addition in this regard for reasons of cost (much lower than steel or carbon fibre) and dispersive power in the cement matrix.

Figure 8 shows the shielding performance by frequency obtained for different carbon materials containing a

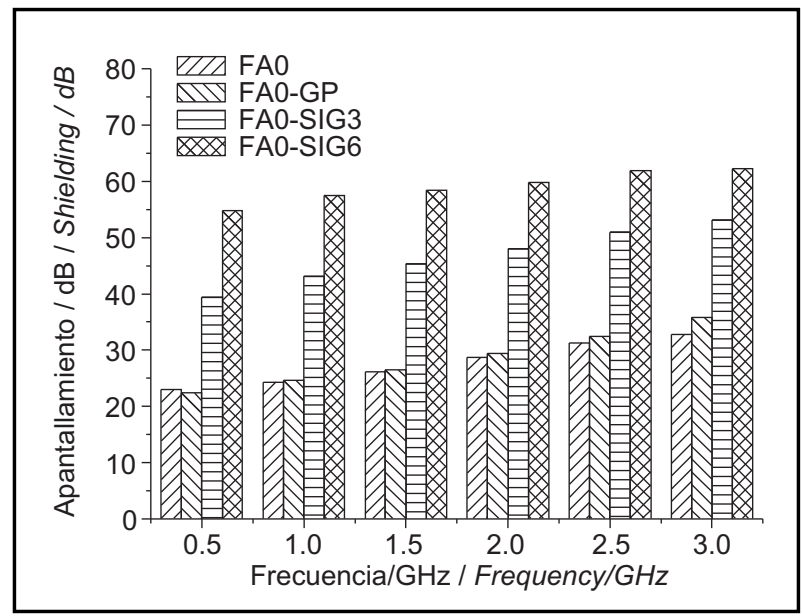

Figura 8. Apantallamiento EMI de probetas de pasta de cemento con ceniza volante original (FA0) y varios materiales carbonosos a distintas frecuencias. Espesor de las probetas: $4 \mathrm{~cm}$.

Figure 8. EMI shielding in 4-cm cement paste specimens containing the original fly ash (FAO), by carbonic material and frequency. 
proporción fija de ceniza volante original para distintas frecuencias. Se puede apreciar claramente el mejor comportamiento que ofrecen nuevamente las fibras (especialmente la SIG6) con respecto al polvo de grafito (GP). Además los valores son superiores a los que se obtuvieron con las mismas fibras en las pastas de cemento Portland sin ceniza volante. Esta mejora se atribuye a dos factores: por un lado, la sola presencia de ceniza volante original ayuda a elevar ligeramente el valor de apantallamiento; y por otra parte, parece ser que la ceniza volante puede ayudar a mejorar la dispersión de las fibras de carbono. Cabe destacar que la pasta FA0-SIG6 ofrece un valor de apantallamiento del orden de los $60 \mathrm{~dB}$ para frecuencias superiores a 2,0 $\mathrm{GHz}$, lo cual se traduce en un apantallamiento del $99,90 \%$ de la intensidad de radiación incidente.

Por último, la Figura 9 muestra los valores de apantallamiento obtenidos en las probetas de pasta de cemento con una cantidad fija de SIG6 y una proporción constante de las distintas fracciones de ceniza volante para las frecuencias estudiadas en este trabajo. En primer lugar se destaca que el hecho de incorporar cualquiera de las fracciones de ceniza volante, produce una importante mejoría de los valores de apantallamiento, especialmente para las frecuencias bajas. De hecho, las pastas que incorporan tanto la fibra como ceniza volante muestran un comportamiento menos dependiente con la frecuencia de la radiación incidente, aunque todavía se aprecia que al aumentar la frecuencia aumenta el nivel de apantallamiento de la pasta. Por otro lado, se vuelve a apreciar que la fracción que mayores valores de apantallamiento muestra es la fracción magnética, seguida de la ceniza volante original y por último, aunque muy próxima a la anterior, la ceniza volante no magnética. Destaca el hecho de que la combinación de un 30\% de ceniza volante magnética con un $0,5 \%$ de SIG6 ofrece un apantallamiento de $73 \mathrm{~dB}$, lo que implica una atenuación de la intensidad de la radiación del 99,97\%. fixed proportion of original fly ash. Note the clearly greater effectiveness obtained with fibres (especially SIG6) than with graphite powder (GP). Moreover, the values found were higher than obtained with the same fibres in Portland cement paste prepared without fly ash. This improvement was attributed, on the one hand, to the mere presence of the original fly ash, which enhanced shielding slightly, and on the other to its apparent contribution to the dispersion of the carbon fibres. Paste FAO-SIG6 exhibited shielding on the order of $60 \mathrm{~dB}$ at frequencies of over $2.0 \mathrm{GHz}$, i.e., a shielding capacity of $99.90 \%$ of the intensity of the incident radiation.

Lastly, Figure 9 shows the shielding values found for cement paste specimens with a fixed amount of SIG6 and a constant proportion of the different fractions of fly ash at the frequencies studied here. The first finding was that all the fractions of fly ash visibly improved shielding values, particularly at low frequencies. In fact, the pastes containing both fibre and fly ash proved to be less dependent upon radiation frequency, even though paste shielding power was greater at higher frequencies. In any event, the magnetic fraction exhibited the highest shielding capacity, followed by the original fly ash and the non-magnetic fraction in that order, but with very similar values. The shielding effectiveness attained with a combination of $30 \%$ magnetic fly ash and $0.5 \%$ SIG6 was $73 d B$, which translated into $99.97 \%$ attenuation of the radiation intensity.

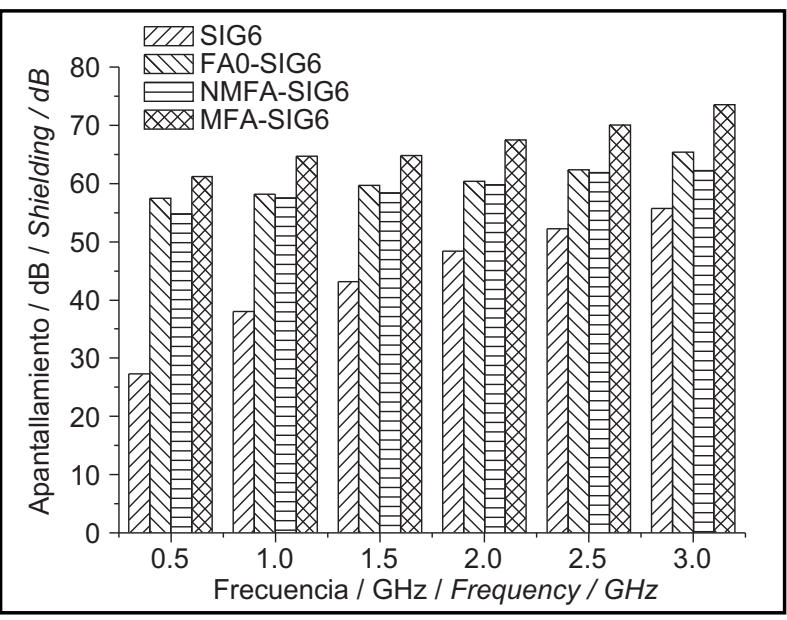

Figura 9. Apantallamiento EMI de probetas de pasta de cemento con SIG6 y varias fracciones de ceniza volante procesada a distintas frecuencias. Espesor de las probetas: $4 \mathrm{~cm}$.

Figure 9. EMI shielding in 4-cm cement paste specimens containing SIG6 and different fractions of fly ash, by frequency. 


\section{CONCLUSIONES}

Las conclusiones más relevantes que se han obtenido de este trabajo son las que se detallan a continuación:

- El nivel de apantallamiento de radiaciones electromagnéticas depende del tipo de material de carbón utilizado.

- El nivel de apantallamiento aumenta al aumentar la relación de aspecto (longitud/ diámetro) del material de carbón utilizado.

- Al aumentar el espesor de la muestra bajo estudio se mejora la eficacia del apantallamiento registrado.

- La adición, por sí sola, de ceniza volante a una pasta cementicia implica un aumento del nivel de apantallamiento.

- La fracción magnética que se obtiene mediante el tratamiento de cenizas volantes con campos magnéticos aumenta el nivel de apantallamiento de radiaciones electromagnéticas.

- La adición conjunta de material de carbón y ceniza volante implica un efecto sinérgico a la hora de aumentar el nivel de apantallamiento que presentan estos materiales por separado, lo cual se cree que se debe a la que la ceniza volante ayuda a mejorar la dispersión de la fibra de carbono en la matriz.

\section{AGRADECIMIENTOS}

Los autores agradecen la financiación concedida a través de los siguientes proyectos para la realización de este trabajo: BIA 2006-10703 del Ministerio de Educación y Ciencia, C63/2006 del Ministerio de Fomento, y BIA200910866 del Ministerio de Ciencia e Innovación. E. Zornoza agradece al Ministerio de Ciencia e Innovación su inclusión en el Programa Juan de la Cierva.

\section{CONCLUSIONS}

The most prominent conclusions drawn from the present research are listed below.

- The level of electromagnetic radiation shielding depends on the type of carbon material used.

- Shielding capacity increases with the aspect ratio (length/diameter) of the carbon material used.

- The thicker the specimen, the greater the shielding effectiveness.

- The addition of fly ash alone to a cementitious paste raises the shielding value.

- When added to cement pastes, the magnetic fraction obtained by subjecting fly ash to magnetic fields raises the electromagnetic radiation shielding capacity of the paste.

- The combined addition of carbon material and fly ash generates synergies, increasing the shielding capacity by more than the sum of the effect of these two materials taken separately. Such synergies are attributed to the enhanced dispersion of carbon fibres in the cement matrix in the presence of fly ash.

\section{ACKNOWLEDGEMENTS}

This research was funded under Spanish Ministry of Education and Science project BIA 2006-10703, Ministry of Internal Development project C63/2006, and Ministry of Science and Innovation project BIA 2009-10866. Author E. Zornoza participated in the study under the Ministry of Science and Innovation's Juan de la Cierva Programme.

\section{BIBLIOGRAFÍA / BIBLIOGRAPHY}

(1) Chung, D. D. L.: "Functional Properties of Cement-Matrix Composites", J. Mater. Sci. 36 (2001), pp. 1315-1324. doi:10.1023/A:1017522616006

(2) Chung, D. D. L.: "Materials for Electromagnetic Interference Shielding", J. Mater. Eng. Perf. 9(3) (2000), pp. 350-354. doi:10.1361/105994900770346042

(3) Chung, D. D. L.: "Carbon fiber cement-matrix composites", Tanso, no 190, (1999), pp. 300-312.

(4) Wu, Junhua; Chung, D. D. L.: "Pastes for electromagnetic interference shielding", Journal of Electronic Materials, vol. 34, no 9 (2005).

(5) Kovalchuk, G.; Fernández-Jiménez, A.; Palomo, A.: "Alkali-activated fly ash. Relationship between mechanical strength gains and initial ash chemistry", Materiales de Construcción, 58: 291 (2008), pp. 35-52.

(6) Menéndez, G.; Bonavetti, V. L.; Irassar, E. F.: "Ternary blended cement concrete. Part I: early age properties and mechanical strength", Materiales de Construcción, 56: 284 (2006), pp. 55-67.

(7) Goñi, S.; Guerrero, A.: "Hydraulic activity of belite cement from class C coal fly ash. Effect of curing and admixtures", Materiales de Construcción, 56: 283 (2006), pp. 61-77.

(8) Fernández-Jiménez, A.; Palomo, A.: "Factors affecting early compressive strength of alkali activated fly ash (OPC-free) concrete", Materiales de Construcción, 57: 287 (2007), pp. 7-22.

(9) Cao, Jingyao; Chung, D. D. L.: "Use of fly ash as an admixture for electromagnetic interference shielding", Cement and Concrete Research, 34 (2004), pp. 1889-1892. doi:10.1016/j.cemconres.2004.02.003 
(10) Garcés, P.; Andión, L.G.; Zornoza, E.; Bonilla, M.; Payá, J. "The effect of processed fly ashes on the durability and the corrosion of steel rebars embedded in cement-modified fly ash mortars". Cement and Concrete Composites 32:3 (2010) 204-210. doi: 10.1016/j.cemconcomp.2009.11.006

(11) Fu, Xuli and Chung, D. D. L.: "Submicron carbon filament cement-matrix composites for electromagnetic interference shielding", Cement and Concrete Research, vol. 26, no 10, pp. 1467-1472, 1996. doi:10.1016/0008-8846(96)00146-9

(12) Fu, Xuli; Chung, D. D. L.: "Radio-wave-reflecting concrete for lateral guidance in automatic highways", Cement and Concrete Research, vol. 28, no 6 (1998), pp. 795-801. doi:10.1016/S0008-8846(98)00057-X

(13) Wen, Sihai; Chung, D. D. L.: "Electromagnetic interference shielding reaching $70 \mathrm{~dB}$ in steel fiber cement", Cement and Concrete Research, 34 (2004), pp. 329-332. doi:10.1016/j.cemconres.2003.08.014

(14) Chen, P.-W.; Chung, D. D. L.: "Improving the Electrical Conductivity of Composites Comprised of Short Conducting Fibers in a NonConducting Matrix: the Addition of a Non-Conducting Particulate Filler", J. Electron. Mater. 24 (1) (1995), pp. 47-51. doi:10.1007/BF02659726

(15) Cao, J.; Chung, D. D. L.: "Colloidal graphite as an admixture in cement and as a coating on cement for electromagnetic interference shielding", Cement and Concrete Research, 33 (2003), pp. 1737-1740. doi:10.1016/S0008-8846(03)00152-2

(16) Cao, J.; Chung, D. D. L.: "Coke powder as an admixture in cement for electromagnetic interference shielding", Carbon 41 (2003), pp. 2427-2451. doi:10.1016/S0008-6223(03)00289-6

(17) Chiou, J.-M.; Zheng, Q.; Chung, D. D. L.: "Electromagnetic interference shielding by carbon fibre reinforced cement", Composites, 20 (1989), pp. 379-381. doi:10.1016/0010-4361(89)90663-0

(18) Chung, D. D. L.: "Electromagnetic interference shielding effectiveness of carbon materials", Carbon 39 (2001), pp. $279-285$. doi:10.1016/S0008-6223(00)00184-6

(19) Payá, J.; Borrachero, M. V.; Monzó, J.; Peris-Mora, E.; Bonilla, M.: "Long term mechanical strength behaviour in fly ash/Portland cement mortars prepared using processed ashes", Journal of Chemical Technology and Biotechnology, 77 (2002), pp. 336-344. doi: $10.1002 /$ jctb. 580

(20) Guan, H.; Liu, S.; Duan, Y.; Cheng, J.: "Cement based electromagnetic shielding and absorbing building materials", Cement \& Concrete Composites, 28 (2006), pp. 468-474. doi:10.1016/j.cemconcomp.2005.12.004

(21) Guan, H.; Liu, S.; Duan, Y.; Zhao, Y.: "Investigation of the electromagnectic characteristics of cement based composites filled with EPS", Cement \& Concrete Composites, 29 (2007), pp. 49-54. doi:10.1016/j.cemconcomp.2006.08.001

(22) Akkurt, I.; Basyigit, C.; Kilincarslan, S.; Mavi, B.; Akkurt, A.: "Radiation shielding of concretes containing different aggregates", Cement \& Concrete Composites, 28 (2006), pp. 153-157. doi:10.1016/j.cemconcomp.2005.09.006

(23) Wen, S.; Chung, D. D. L.: "Partial replacement of carbon fiber by carbon black in multifunctional cement-matrix composites", Carbon 45 (2007), pp. 505-513. doi:10.1016/j.carbon.2006.10.024

(24) Chung, D. D. L.: "Electrically conductive cement-based materials", Advances in Cement Research, 16 (2004), pp. 167-176.

(25) Shi, Z.-Q.; Chung, D. D. L.: "Concrete for magnetic shielding", Cement and Concrete Research, 25:5 (1995), pp. 939-944. doi:10.1016/0008-8846(95)00087-S

(26) Wang, C.; Li, K.; Li, H.; Guo, L.; Jiao, G.: "Influence of CVI treatment of carbon fibers on the electromagnetic interference of CFRC composites", Cement \& Concrete Composites, 30 (2008), pp. 478-485. doi:10.1016/j.cemconcomp.2007.09.002

(27) Li, K.; Wang, C.; Li, H.; X. Li; Ouyang, H.: "Effect of chemical vapor deposition treatment of carbon fibers on the reflectivity of carbon fiber-reinforced cement-based composites", Composite Science \& Technology, 68 (2008), pp. 1105-1114. doi:10.1016/j.compscitech.2007.08.003

(28) Bhattacharya, S.; Sachdev, V. K.; Chatterjee, R.; Tandon, R. P.: "Decisive properties of graphite-filled cement composites for device application", Applied Physics A, 92 (2008), pp. 417-420. doi:10.1007/s00339-008-4544-9 